\title{
Can the FIFA world cup football (soccer) tournament be associated with an increase in domestic abuse?
}

\author{
Dr Stuart Kirby* \\ Department of Applied Social Science, Lancaster University, Lancaster, UK \\ Professor Brian Francis \\ Department of Mathematics and Statistics, Lancaster University, Lancaster, UK \\ Ms Rosalie O'Flaherty, \\ Department of Applied Social Science, Lancaster University, Lancaster, UK \\ *Any queries should be directed to the lead author, e-mail: s.kirby@lancaster.ac.uk
}

\begin{abstract}
Objectives

This study aims to establish whether empirical evidence exists to support the anecdotal view that the FIFA world cup football (soccer) tournament can be associated with a rise in reported domestic abuse incidents, when viewed remotely via television.
\end{abstract}

Methods

A quantitative analysis, using Poisson and negative binomial regression models looked at monthly and daily domestic abuse incidents reported to a police force in the North West of England across three separate tournaments (2002, 2006, 2010).

Results

The study found two statistically significant trends. A match day trend showed the risk of domestic abuse rose by $26 \%$ when the English national team won or drew, and a $38 \%$ increase when the national team lost. Secondly a tournament trend was apparent, as reported domestic abuse incidents increased in frequency with each new tournament.

\section{Conclusions}

Although this is a relatively small study it has significant ramifications due to the global nature of televised football (soccer) tournaments. If replicated it presents significant opportunities to identify and reduce incidents of domestic abuse associated with televised soccer games. 


\section{Introduction}

Immediately prior to the 2010 FIFA football (soccer) world cup tournament UK news agencies published a variety of headlines warning of an associated increase in domestic violence (Fresco \& Sanderson, 2010; BBC News, 2010; Baron, 2010). However, although raising awareness, these reports lacked sufficient detail or scientific validity to sustain a wider debate or generate any systematic intervention. The notion that a televised football (soccer) tournament, whilst viewed remotely, could generate a social stimulus powerful enough to be associated with an increase in domestic abuse has significant ramifications. This is because soccer continues to evolve as a global business; the English Premier League, for example, involves 337 foreign players from 66 countries with games being televised to over 200 countries. Other European leagues, such as La Liga (Spain), Serie A (Italy) and Bundesliga (Germany) are also televised internationally with the European Champions League final watched by 109 million people across the world (The Barclays Premier League, 2011). In an increasingly diverse and globalised world soccer is no longer a local pastime but generates allegiance from supporters across the developed world. It is therefore important to establish whether an association with domestic violence is a social myth, or whether it can be confirmed through empirical evidence.

\section{Theoretical background}

Although there is no published study exploring the relationship between the viewing of televised soccer and domestic abuse there is a body of research that suggests this association could exist. Although commentators argue the complexity of domestic abuse requires a multi-faceted explanation, attempts to explain it have generally fallen between individual and social-structural accounts (Robinson, 2010). Individual or psychological explanations highlight the importance of personal factors, an example being 'social learning theory' that argues specific behaviour is determined through watching others. As commentators have argued, "Being a victim of physical abuse, or witnessing the abuse of other family members, teaches boys to become violent" (Bevan and Higgins, 2002: 225), and "the girl, seeing her mother as a victim of violence, chooses a violent partner and ... becomes the victim" (Lockton and 
Ward, 1997: 29), thereby creating a cycle of violence (Fagan, 2005). Other psychological explanations include: mental health problems (which can also emanate from a difficult upbringing); post- traumatic stress disorder; anxiety; depression; poor anger management; dissociation; frustration and substance abuse.

Conversely social-structural explanations, often created through feminist-led research, have focused on wider cultural factors, specifically the imbalance of power between males and females. In this way violence is viewed as a symptom of wider situational concerns, being "....both a product and an expression (or 'performance') of socialization, genderization, and acculturation into narrow and persisting values of 'being a man', and into a society underpinned by asymmetrical power relations' (Thurston and Beynon, 1995: 181). 'Lashing out at their partner can therefore be used to endorse impressions of masculinity or serve as a cathartic release to feelings of male inadequacy generated through social problems such as unemployment, poverty, or everyday stresses' (Agnew, 1985: 151). Indeed an increase in domestic abuse has been associated with periods of high unemployment (Lockton and Ward, 1997: 28), and recession (Morris and Grady, 2009).

Turning more specifically towards soccer, the game has experienced a long cultural association with both violence and masculinity. Carnibella et al. (1996), have pointed out that general acts of violence have been associated with the game since its origins in $13^{\text {th }}$ Century England and observed across much of Europe; specifically England, Italy, Netherlands, Germany, Spain, France, Czech Republic, Greece and Albania. In fact Quigg et al. (2010) found the 2010 world cup tournament was associated with a $37.5 \%$ rise in admission rates across 15 hospital emergency departments on England match days. There also appears a similar phenomenon with American football; Rees \& Schnepel (2009) found increased reports of assault, vandalism and arrests for disorderly conduct and alcohol related offences whilst monitoring six seasons of college football. Similar to domestic abuse commentators argue there is no universal explanation for football associated violence explaining different reasons exist, dependent on country and situation. However such explanations again generally follow individual and socio-cultural explanations. For example studies have 
suggested that testosterone levels increase in individuals when watching football matches, a chemical associated with an upsurge in aggression, causing Bernhardt et al. (1998:59) to observe that fans identify with team success or failure as their own. Further Swain (2000: 103) argued, "Football (soccer) is full of aggressive intent, about winners and losers, territorial, space-occupying domination, and where loyalty and commitment to the side are prized values".

Although no prior study has associated soccer with domestic violence this correlation has already been established with American Football. Card \& Dahl (2011) found that home based male-on-female partner violence increased by $10 \%$ following a televised upset loss, experienced by their home NFL team. This behaviour was concentrated at the end of the game and became more pronounced for the most important matches. Other situational factors have also been associated with interpersonal conflict. Television influences both attitude and behaviour not only because of the content but because it generates changes in interpersonal interaction (Dahl \& DellaVigna, 2009). Gantz et al. (2006) established that program preference disputes between husbands and wives are greatest when watching televised sports. Similarly in the UK there has been a move to display soccer games on large screens in public bars bringing individuals together in confined social spaces. Finally, alcohol is a commonly observed factor associated with both football violence and domestic abuse. The risk of partner violence is 'often increased by excessive drinking and poorly managed emotions' (Baron, 2010), a finding supported by Gayford (1975: 196) who, surveying 100 domestic violence victims articulated a picture, “...of men with low frustration tolerance, who often completely lose control under the influence of alcohol". Indeed one study highlighted alcohol consumption as a contributory factor in 36\% of domestic abuse cases (Lockton and Ward, 1997: 28).

These facilitators play a significant role in theories that enhance the importance of context when understanding and reducing crime. Rational Choice Theory (Felson, 2002), for example, argues crime occurs as a result of the normal rhythms of everyday life. In this way commentators have established domestic violence occurs more frequently on weekends (Gantz et al. 2006; Vazquez et al. 2005); and on 
exceptionally warm days and major holidays (Card \& Dahl, 2011). Although Oths \& Robertson (2007) reported no increase in women seeking refuge in 'safe houses' during established 'drinking holidays' (i.e. the U.S. Superbowl), the fact they were more likely to flee during extended school holidays makes it possible this decisionmaking was more aligned to pragmatism than the level of incidents. What does appear clear is that situations have an affect on offending patterns and as new situations are generated they create the conditions for further offences to take place. Extending this view it is possible to imagine how watching the world cup tournament (even remotely), in close proximity to others can heighten the stressors associated with domestic abuse.

Obviously if increased domestic abuse is associated with the world cup tournament then such an understanding can inform interventions to reduce it. As Clarke (1997:4) says 'Situational prevention comprises opportunity-reducing measures that are directed at highly specific forms of crime and involve the management, design or manipulation of the immediate environment in as systemic and permanent way as possible'. However before this approach is explored a much clearer understanding must be gained as to whether domestic violence incidents do increase during the world cup tournament.

\section{Methodology}

The purpose of this research was to establish whether the FIFA world cup tournament was associated with an increase in domestic violence in the UK. Proving or disproving such a hypothesis presents numerous methodological issues; the most obvious being the identification of domestic abuse itself. The terms 'domestic abuse' and 'domestic violence' are often interchanged. Whereas domestic violence more often describes physical assault, domestic abuse is defined more widely and can include 'physical, psychological, sexual or financial violence that takes place within an intimate or family- type relationship, forming a pattern of coercive and controlling 
behaviour' (Women's Aid, 2007). Similarly the term 'domestic' can include "violence between spouses or between parents and children, between non-married partners, siblings, or between those in more distant familial relationships" (Tadros, 2005, cited in Herring, 2008: 378). This diversity conjures up significant difficulty when trying to measure the extent of the problem.

Even when a definition is chosen there is difficulty obtaining accurate data. 'Self report' studies, such as the British Crime Survey (BCS) are generally accepted as the most reliable (Hope, 2004). However one of the weaknesses of the BCS is that it provides annual trends and is insufficiently detailed to monitor the short periods required for this type of analysis. To combat this problem the study uses police data, although gaps are apparent as UK based commentators estimate only $24 \%$ of domestic violence incidents are reported (Walby and Allen, 2004). These low reporting levels have been observed in wider international studies, causing commentators to refer to domestic abuse as the 'hidden violence against women' (Stanko, 1988; Farrell, 1992; Walby, 2005).

However one of the benefits of using UK police data is that domestic abuse incidents are monitored separately to other violent crime. During 1990 UK Home Office circulars $60 \& 139$ both prioritised and standardised the response to domestic abuse, requiring police forces to establish dedicated 'Domestic Violence Officers' and collate incidents accurately (Grace, 1990). This process has not changed significantly and, unlike other violent crime, domestic violence can be recorded with a minimal level of proof - a slap or shove being sufficient to record an incident (Lockton and Ward, 1997). Therefore a database in each Police jurisdiction collates all incidents of domestic abuse and does not require the instigation of a prosecution. As such any flaws in the process have been consistent resulting in more reliable trends. For the purpose of this research recorded incidents include those victims who have reported to the police a violent or threatening act from an individual they are currently (or have recently been), in an intimate relationship with. 
Having established that police data would be used it was decided to analyse the three most recent tournaments: 2002, 2006 and 2010 as well as the years prior to the tournament $(2001,2005,2009)$, to establish any wider trends. The study placed particular scrutiny on the England matches as it was felt these games would increase the stressors associated with the situation. The England fixtures are shown below and the winner of each match is highlighted in bold italic (a draw is indicated by the absence of bold italic.).

$31^{\text {st }}$ May $-30^{\text {th }}$ June 2002 , Hosted by Korea/ Japan:

- Sunday $02^{\text {nd }}$ June (England V Sweden)

- Friday $07^{\text {th }}$ June (England V Argentina)

- Wednesday $12^{\text {th }}$ June (England V Nigeria)

- Saturday $15^{\text {th }}$ June (England V Denmark)

- Friday $21^{\text {st }}$ June (England V Brazil)

$9^{\text {th }}$ June $-9^{\text {th }}$ July 2006, Hosted by Germany:

- Saturday $10^{\text {th }}$ June (England V Paraguay)

- Thursday $15^{\text {th }}$ June (England V Trinidad and Tobago)

- Tuesday $20^{\text {th }}$ June (England V Sweden)

- Sunday $25^{\text {th }}$ June (England V Ecuador)

- Saturday $01^{\text {st }}$ July (England V Portugal)

$11^{\text {th }}$ June $-11^{\text {th }}$ July 2010 , Hosted by South Africa:

- Saturday $12^{\text {th }}$ June (England V USA)

- Friday $18^{\text {th }}$ June (England V Algeria)

- Wednesday $23^{\text {rd }}$ June (England V Slovenia)

- Sunday $27^{\text {th }}$ June (England V Germany) 
(FIFA, 2010)

The Lancashire Constabulary, who with approximately 6,000 staff is the 11th largest of 43 police forces in England and Wales, provided the data. This Constabulary was seen as a suitable agency for a number of reasons. First it polices a diverse area covering a location of 2000 square miles in the North West of England, with a population of 1.4 million divided between urban (Blackburn, Preston), rural (Lancaster) and tourist (Blackpool) locations. Furthermore, the Constabulary acknowledges domestic abuse as a policing priority and has adhered to national standards in relation to information recording.

\section{Method}

The monthly number of police recorded domestic violence incidents for 2001, 2002, 2005, 2006, 2009 and 2010 were obtained from Lancashire Constabulary. In addition, daily counts of recorded domestic violence incidents were obtained for the tournament periods (approximately a month), starting on the 1 st June $2002,1^{\text {st }}$ June 2006 and $1^{\text {st }}$ June 2010 . The daily analysis provides a more detailed examination of day-to day variation, and also allowed the inspection of reported incidents the day after England matches were played. Unfortunately no wider situational variables were available from the police agency. It is also important to note that during the World Cup tournament, soccer matches are played on most days. As such it is felt factors such as a multi cultural population, different team allegiance, and the fact that other team fixtures can affect the England outcome, can all serve to impact upon interpersonal relationships. However, the hypothesis to be tested is that overall, domestic abuse incidents will increase in England on the dates the national (England) team play abroad.

The two sets of data were examined visually as well as statistically through Poisson regression and Poisson negative binomial regression models. Poisson regression is appropriate for count data, and negative binomial is appropriate for count data 
which is over dispersed or where there is unmeasured variability, for example dayto-day variation in weather conditions, or holidays over the period. Negative binomial models are increasingly being used in criminology in victimisation studies; for example, to model repeat victimisation (Tseloni,2006) and exposure to violence (Reingle et al, 2011).

Main effects Poisson models were first fitted to the observed monthly counts of the domestic abuse incidents. If this model failed to fit (according to the likelihood ratio goodness of fit statistic $\mathrm{G}^{2}$ ), then it would be replaced with the negative binomial model. For the monthly analysis, an exposure variable of the number of days in the month was also included in the model as well as year, and month of year (12 levels). A dummy identifying world cup month was specified as explanatory categorical factors. Formally, this model can be written as:

$$
\begin{aligned}
& \ln \left(C_{i}\right)=\eta_{\mathrm{i}}=\ln \left(E_{i}\right)+\alpha_{j}+\beta_{k}+\gamma_{l} \\
& \text { with } C_{i} \sim \text { Poisson }\left(E_{i} \lambda_{i}\right) \text { or } C_{i} \sim \text { Negative Binomial }\left(E_{i} \lambda_{i}, \theta\right)
\end{aligned}
$$

where $C_{i}$ represents the observed monthly counts, $E_{i}$ is the exposure variable for month $i$, and $\alpha, \beta$ and $y$ represent the effects of year, month of year and world cup month respectively. $\lambda_{i}$ is the mean daily reporting rate of domestic violence, and $\vartheta$ is the overdispersion parameter for the negative binomial distribution, with dispersion set to $1+\vartheta \exp \left(\eta_{i}\right)$. A dispersion parameter $\vartheta$ of zero therefore indicates no overdispersion.

For the daily count analysis, a similar model was fitted. Explanatory factors were year (three levels), day of week (dow-seven levels) and a four level factor named 'match' indicating whether the day was the day of an England match with an England loss, the day of an England match with an England win or draw, the day after an England match or a non-match day (all other days). No exposure variable was needed for this second analysis, as the exposure time was the same for all observations. For each analysis, the exponent of the parameter estimates is reported - that is, $\exp \left(\alpha_{j}\right), \exp \left(\beta_{k}\right)$ and $\exp \left(\eta_{l}\right)$ - which can be interpreted as multiplicative 
relative risks compared to the relevant baseline category of the appropriate categorical factor.

\section{Exploratory analysis}

Table 1 provides numerical information detailing the incidents of domestic violence reported to the police in Lancashire on a monthly and annual basis during the FIFA world cup tournament years. The years prior to the tournament are also included for comparative reasons. A visual examination of the table highlights two important points. First, during December 2001, the rate of reported domestic violence more than doubled compared to previous months and then remained at this higher level. This can be explained by well publicised national changes to the UK crime recording protocols that were associated with a national increase in the recording of violent crime (Simmons et al. 2003; Maguire, 2012). Second, from 2002-2010 there is a small but steady increase in the reporting of domestic violence to the police. This occurred whilst the general level of reported crime fell significantly and the British Crime Survey, also revealed a reduction in victim reports of domestic violence - from around 987, 000 incidents in 1996, to an estimated 293,000 incidents in 2008 (Roe et al. 2009: 16). Again this finding can easily be explained by the UK policy changes, explained earlier, which encouraged more victims to report domestic abuse to the Police (Lockton \& Ward, 1997).

\section{INSERT TABLE 1 HERE}

Table 2 provides visual evidence of an increase in reporting domestic violence incidents on the days England played. The average number of incidents reported on the days England played was 79.3, compared with 58.2 on the days they did not play. There also seemed to be some evidence that incidents were often high on the day following an England game, with a mean number of incidents of 70.5 .

Secondly, the trend in domestic violence appears to be increasing in severity across the 3 tournaments as during 2002 the average number of incidents reported during 
the day of an England game was 64, during 2006 it was 78 incidents and during 2010 it was 99 incidents. Indeed the final day of the tournament for the England team in both 2006 and 2010 exhibited the highest level of reported incidents for the entire month. Also, whenever the England game was played on a weekend this was associated with a higher number of reported domestic violence incidents.

\section{INSERT TABLE 2 HERE}

\section{Statistical analysis}

a) Monthly count data.

Because of the change in national recording practices the data relating to 2001 was removed leaving five years of data to be analysed (2002, 2005, 2006, 2009 and 2010). A Poisson regression model with the three explanatory factors (described earlier) did not fit the data $\left(G^{2}=1393.7\right.$ on $\left.43 \mathrm{df}, \mathrm{p}<0.001\right)$, therefore a negative binomial model was fitted.

The estimate for the relative risk for "world cup month" is 0.972 , indicating a slightly lower risk in June world cup months once month of year and year are controlled for. However both the effect of the dummy "World cup month" and month of year are not statistically significant. A likelihood ratio test dropping, in turn, world cup month from the main effects model, and then separately dropping month of year from the main effects model, gives likelihood ratio test statistics of 0.04 on $1 \mathrm{df}(p=0.84)$ and 11.99 on $11 \mathrm{df}(p=0.34)$ respectively. Year, however is significant (53.71 on $4 \mathrm{df}$, $p<0.001)$. The relative risk estimates for 2005, 2006 and 2009 compared to 2002 are $1.221,1.112$ and 1.132 , showing between a $10 \%$ to $22 \%$ increase in risk compared to 2002. Moreover, there is a substantial increase in reporting for 2010 , the relative risk being estimated at 1.517 , showing a $52 \%$ increase over 2002 . While year by year changes can be detected, the analysis shows that aggregated monthly data, often used by UK police analysts, may be too coarse to identify day-to-day fluctuations in reported incidents of domestic abuse. As a result, the principal analysis examined daily counts. 
b) Daily count data

As with the monthly counts, a Poisson main effects model failed to fit the data (G2=163.1 on $80 \mathrm{df} ; \mathrm{p}<0.001$ ) and so a negative binomial model was fitted. The results of this model are shown in Table 3. Likelihood ratio tests of the effects of each of the categorical factors were all highly significant (match 23.24 on $3 \mathrm{df}$, $p<0.001$; year 70.00 on 2 df, $p<0.001$; dow 58.33 on 6 df, $p<0.001$ ). The relative risk estimates shown in Table 3 show some interesting results. Examination of the match day variable shows that the relative risk of domestic violence increases by $26 \%$ $(R R=1.256)$ on a match day when England win or draw; and increases by $38 \%$ $(R R=1.380)$ if England lose. There was also some evidence of a small increase in relative risk (11\%), for the day following match day, compared to a non-match day, with the effect just reaching conventional levels of statistical significance on a Wald test $(R R=1.107, p=0.042)$. Day of week effects were also highly significant. Taking a reference day of Thursday, all other days showed a raised relative risk, although only Saturday $(R R=1.435)$ and Sunday $(R R=1.506)$ showed statistically raised relative risks. Finally the year effect showed a raised risk of $10 \%$ for 2006 and a $52 \%$ raised risk for 2010 , compared to the baseline year of 2002 , which is consistent with the monthly data analysis.

\section{INSERT TABLE 3 HERE}

\section{Discussion}

The aim of this study was to establish whether the FIFA World cup football (soccer) tournament, when viewed remotely via television, could be associated with a rise in domestic abuse incidents. Although there are numerous methodological issues surrounding the accurate identification and collection of incidents, the study provides a statistically significant finding that domestic abuse does increase in England on the days when the English national team played in the foreign tournament. Although incidents increased when the team won or drew (26\%), this finding intensified when the England team lost and exited the competition (38\%). 
The study also showed two other interesting trends, one of which was the day after the England game there was an $11 \%$ increase in incidents, after controlling for other factors, which was just statistically significant $(p=0.042)$. It should be noted some matches were staged during the late afternoon or evening meaning some individuals only returned home during the early hours of the following morning, when the abuse would be committed. Further a tournament trend is apparent with incidents following the England game, increasing in frequency with each new competition (2002: mean 64 incidents; 2006: mean 78 incidents; 2010: mean 99 incidents). There may be a number of reasons for this, such as the heightened awareness encouraging victims to report. However if, as intimated by practitioners, this is a real increase caused through the increased commercialism of the tournament, then this bodes worryingly for the future. Indeed during this research the practitioners spoken to were all aware of the problem. A Social Services representative said, "The tournament goes on for a whole month - this creates all sorts of problems, often aggravated by alcohol, on the smallest of issues such as what programme the TV is tuned into". This opinion was also replicated by a Police representative, who added, "The world cup appears a reason for many to party, however delight and expectation can turn into despair and conflict with the kick of a ball".

These results support previous studies that have generally found an increase of aggression associated with soccer and American Football. It also shows that this aggression can extend to domestic abuse when soccer is watched remotely, a finding previously highlighted with American football (Card \& Dahl, 2011). This result complements, rather than contradicts, existing individual and socio-structural explanations relating to domestic or football related violence. Even though the tournament is staged thousands of miles away the live imagery and media commentary is transmitted into homes and social areas, replicating many of the emotions associated with viewing the game in a live environment. These emotional stressors are combined with other situational factors. The tournament is held in the summer and is associated with warmer temperatures, increased alcohol consumption and brings individuals in closer proximity to others. Although it is difficult to say the tournament is a causal factor the prestigious tournament does 
concentrate the risk factors into a short and volatile period thereby intensifying the concepts of masculinity, rivalry and aggression. This process also appears cumulative, as it is not the actual world cup tournament that heightens the risk, but specifically when the England team play. Similarly if the England game is staged on a weekend (days traditionally associated with longer and busier licensing hours and associated disorder (Kirby \& Hewitt, 2011), then incidents are likely to increase further. Further if the England team lose and are knocked out of the tournament then this is associated with further violence.

These findings are important for the prevention of domestic abuse. Understanding the underlying cause of a crime can lead to the most appropriate intervention to reduce or remove it. If increased domestic abuse can be associated with a specific, predictable and short-term event, such as the world cup tournament, then interventions can be tailored to reduce the misery of abused partners as well as the children and family members in proximity to it (Crisp and Stanko, 2001).

This raises the value of an approach which in recent years been aligned with the term 'situational crime prevention'. It proposes that research should "pay much less attention to the causes of crime and much more on how crime is committed and, consequently, how it might be prevented" (Clarke, 2004, cited in Newburn, 2007: 294). Situational crime prevention encompasses numerous theories, perhaps the most notable being Rational Choice Theory (mentioned earlier), which focuses upon how the situation can create the opportunity for crime or disorder to occur (Felson, 2002). In this way the approach argues that "rather than focusing on distant causes such as poverty and social inequality- which have generally proved rather resistant to change- criminologists should look more to the immediate matters that can be manipulated and which might have some practical benefit" (Clarke, 2004, ibid). In this context academics and community safety practitioners should concentrate on establishing how the situation can be changed to reduce the level of domestic violence. Consideration of appropriate and effective interventions requires more space than this current study is able to provide, however Clarke (2004) assists by providing a framework based upon 'Rational Choice Theory'. Clarke argues by 
concentrating on interventions that: increase the effort and risk for the offender; reduce the rewards obtained; or reduce the provocation or excuse the offender says precipitates the offence, then the potential offender can be dissuaded from committing the criminal action. Such an approach enables all those involved in the situation to be involved in the solution. For example Rees \& Schnepel (2009) have shown diminished alcohol consumption can reduce violence following American football matches. Further, it could be that professional players and managers involved in the tournament can publicise their contempt of domestic violence, thereby distancing the aggression on the pitch from the domestic environment. Similarly domestic violence workers can attempt to reduce critical flashpoints occurring, or maximise their resources surrounding national games to ensure positive action is provided.

This study is limited in size, however due to the global explosion of televised soccer, it potentially has significant implications. Clearly it is important to ascertain whether this finding is replicated across the UK or other countries. Similarly further research is required to distinguish the situational factors associated with this finding, an approach unavailable to this study due to the limitations of the data. Specifically it would be useful to understand: where and when the violence occurred, the precipitating factors prior to it occurring; the level of violence; consumption of drugs or alcohol; and a comparison between the expected and final result. As the FIFA world cup tournament is only one of numerous high profile football competitions staged across many continents the potential for associated incidents of domestic abuse is significant. Understanding how these events generate such abuse is critical to reducing them. 


\section{References}

Agnew, R. (1985) 'A Revised Strain Theory of Delinquency', Social Forces, Vol. 64, No. 1, pp. 151- 167.

Baron, J. (07/06/10) Police bid to cut World Cup domestic violence in Leeds, Guardian Leeds, http://www.guardian.co.uk/leeds/2010/jun/07/police-bid-to-cut-world-cupdomestic-violence-in-leeds, [19/04/11].

BBC News. (11/11/2009) 'Rise in UK Unemployment Slowing', BBC News, http://news.bbc.co.uk/1/hi/8353933.stm, [29/04/2011].

BBC News. (25/05/2010) 'Warning of Increased Domestic Abuse', BBC News, http://news.bbc.co.uk/1/hi/uk/8703030.stm, [28/04/2011].

Bernhardt, P.C., Dabbs, J.M., Jr., Fielden, J.A. and Lutter, C.D. (1998) 'Testosterone Changes During Vicarious Experiences of Winning and Losing Among Fans at Sporting Events', Physiology and Behavior, Vol. 65 (1), pp. 59- 62.

Bevan, E. and Higgins, D. J. (2002) 'Is Domestic Violence Learned? The Contribution of Five Forms of Child Maltreatment to Men's Violence and Adjustment', Journal of Family Violence, Vol. 17 (3), pp. 223- 245.

Card, D. and Dahl, G. (2011), 'Family violence and football: The effect of unexpected emotional cues on violent behaviour', The Quarterly Journal of Economics, Vol. 126, pp 103-143.

Carnibella, G., Fox, A., Fox, K., McCann, J., Marsh, J., \& Marsh, P. (1996) Football violence in Europe Oxford: Social Issues Research Centre.

Clarke, R.V. (1997) Situational Crime Prevention: Successful Case Studies ( $2^{\text {nd }}$ edn), Guilderland, N.Y.: Harrow and Heston.

CPS, (2005) 'CPS Domestic Violence- Good Practise Guidance', Crown Prosecution Service. http://www.cps.gov.uk/publications/docs/dv protocol goodpractice.pdf, [21/04/11], pp. 1- 20.

Crisp, D. and Stanko, B. (2001) 'Monitoring costs and evaluating needs', Chapter 12., in Taylor- Browne, J. What Works In Reducing Domestic Violence? A Comprehensive Guide for Professionals, London: Whiting \& Birch, pp. 335- 359. 
Dahl, G. \& DellaVigna, S. (2009), Does movie violence increase violent crime? The Quarterly Journal of Economics, Vol. 124 (2), pp.677-734.

Fagan, A. (2005) 'The Relationship Between Adolescent Physical Abuse and Criminal Offending: Support for an Enduring and Generalized Cycle of Violence', Journal of Family Violence, Vol. 20, No. 5, pp. 279- 290.

Farrell, G. (1992) 'Multiple Victimisation: Its Extent and Significance', International Review of Victimology, Vol. 2, pp. 85- 102.

Felson, M. (2002) 'Crime and everyday life' (3rd edn). CA: Pine Forge Press.

Fresco, A. and Sanderson, D. (11/06/2010) 'Women's Charity Fears World Cup Surge in Domestic Violence', The Times, http://www.timesonline.co.uk/tol/news/uk/article7148019.ece, Accessed 28/04/2011.

Gantz, W., Wang, Z., and Bradley, S. (2006) 'Televised NFL Games, the Family, and Domestic Violence', Chapter 22, pp. 365- 382., in Raney, A.A. and Bryant, J., Handbook of Sport and Media, New Jersey: Lawrence Erlbaum Associates,.

Gayford, J.J. (1975) 'Wife Battering: a Preliminary Survey of 100 Cases', British Medical Journal, Vol. 1, pp. 194- 197.

Government Statistics. (August 2006) 'Government Statistics on Domestic ViolenceEstimated numbers of incidents of domestic violence: England and Wales 1995 2005/06', Dewar Research, http://www.dewar4research.org/DOCS/dvg-v3.pdf, Accessed 27/04/2011.

Grace, S (1990), Policing Domestic Violence in the 1990's. Home Office Research and planning Unit research paper 139, London: HMSO.

Herring, J. (2008) Criminal Law: Text, Cases, and Materials, (3 ${ }^{\text {rd }}$ edition), Oxford: Oxford University Press.

Home Office, (Aug 2010) User Guide to Home Office Crime Statistics, Home Office http://webarchive.nationalarchives.gov.uk/20110220105210/http://rds.homeoffice. gov.uk/rds/pdfs10/crimestats-userguide.pdf, Accessed 19/04/11.

Hope, T. (2004), 'What do crime statistics tell us?', in Hale, C., Hayward, K., Wahidin, A. and Wincup, E. (eds.), Criminology, Oxford: Oxford University Press. 
Kirby, S. and Hewitt, L. (2011), The impact of the Licensing Act 2003 on drinking habits, offences of crime and disorder and policing, in England's newest city, Safer communities, 10(1), pp31-38.

Knight, A. (07/04/2002) 'News in Brief', Community Care, Issue 1429.

Lockton, D. and Ward, R. (1997) Domestic Violence, London: Cavendish

Morris, N. and O' Grady, S. (10/02/2009) 'This is the worst recession for over 100 years', The Independent, http://www.independent.co.uk/news/uk/politics/this-is-the-worst-recession-forover-100-years-1605367.html, Accessed 29/04/2011.

Newburn, T. (2007) Criminology, Cullompton: Willan Publishing.

Oths, K.S., and Robertson, T. (2007) 'Give me shelter: Temporal patterns of women fleeing domestic abuse', Human Organization, 66 (3), pp. 249-260.

Quigg, Z., Hughes, K. \& Bellis, M.A. (2012), 'Effects of the 2010 World cup football tournament on emergency department assault attendances in England' European Journal of Public Health. Doi: 10.1093/europub/cks098. First published on line 8.12.12.

Rees, D.I. and Schnepel, K.T. (2009) 'College Football Games and Crime', Journal of Sports Economics, 10(68), pp. 68-87.

Reingle, J.M., Jennings, W.G., Maldonado-Molina, M.M., Piquero, A., and Canino, G. (2011) 'Investigating the role of gender and delinquency in exposure to violence among Puerto Rican youth' Journal of Contemporary Criminal Justice, 27, pp. 361377.

Robinson, A. (2010) 'Domestic Violence' in Brookman, F., Maguire, M., Pierpoint, H. and Bennet, T. (eds), Handbook on Crime, Collumpton: Willan Publishing.

Roe, S., Coleman, K. and Kaiza, P. (2009) 'Violent and Sexual Crime', Home Office, http://www.crimestoppers-uk.org/webfiles/stats/2008-09/bcs-violent-and-sexualcrime08-09.pdf, Accessed 28/04/2011.

Stanko, E.A. (1988) 'Hidden Violence Against Women' in Maguire, M. and Pointing, J. (eds), Victims of Crime: A New Deal? Milton Keynes: Open University Press. 
Swain, J. (2000) "The Money's Good, the Fame's Good, the Girls are Good: The role of playground football in the construction of young boys' masculinity in a junior school', British Journal of Sociology of Education, Vol. 21 (1), pp. 95- 109.

The official website of the Barclays Premier League (2011).

http://www.premierleague.com/page/faqs. Accessed 29.10.11

Thurston, R. and Beynon, J. (1995). 'Men's own stories, lives and violence: Research as practice', in Dobash, R.E., Dobash, R.P. and Noaks, L. (eds), Gender and Crime. Cardiff: University of Wales Press.

Tseloni, A. (2006) 'Multilevel modelling of the number of property crimes: household and area effects' Journal of the Royal Statistical Society Series A 169(2) pp. 205-233

Vazquez, S., Stohr, M.K., and Purkiss, M. (2005) 'Intimate Partner Violence Incidence and Characteristics: Idaho NIBRS 1995-2001 Data' Criminal Justice Policy Review, 16 (March), pp 99-114.

Walby, S. (2005) 'Improving the Statistics on Violence Against Women', Statistical Journal of the United Nations Economic Commission for Europe, Vol. 22 (3\&4), pp. 193- 216.

Walby, S. and Allen, J. (2004) 'Domestic violence, sexual assault and stalking: Findings from the British Crime Survey', Home Office Research Study 276, London: Home Office Research, Development and Statistics Directorate

Women's Aid. (30/11/2007) 'What is Domestic Violence?', Women's Aid, http://www.womensaid.org.uk/domestic-violencearticles.asp?section $=00010001002200410001$ \&itemid=1272, Accessed 28/04/2011. 
Table 1. The monthly number of domestic violence incidents reported to the Lancashire Constabulary.

\begin{tabular}{|l|r|r|r|r|r|r|}
\hline & \multicolumn{5}{|c|}{ Year } \\
\hline & 2001 & 2002 & 2005 & 2006 & 2009 & 2010 \\
\hline Month & & & & & & \\
\hline January & 481 & 1503 & 1837 & 1683 & 1312 & 2234 \\
\hline February & 477 & 1384 & 1556 & 1477 & 1233 & 1978 \\
\hline March & 688 & 1516 & 1773 & 1518 & 1290 & 2142 \\
\hline April & 755 & 1359 & 1853 & 1615 & 1332 & 2154 \\
\hline May & 749 & 1439 & 1985 & 1638 & 1374 & 2342 \\
\hline June & 784 & 1596 & 1838 & 1682 & 1376 & 2328 \\
\hline July & 636 & 1483 & 1743 & 1727 & 2513 & 2360 \\
\hline August & 562 & 1370 & 1701 & 1592 & 2105 & 2060 \\
\hline September & 561 & 1315 & 1742 & 1476 & 2141 & 2243 \\
\hline October & 645 & 1384 & 1602 & 1497 & 2026 & 2231 \\
\hline November & 1611 & 1800 & 1868 & 1708 & 2198 & 2249 \\
\hline December & & 17586 & 21496 & 19548 & 20122 & 26653 \\
\hline Tot AL & & & 1998 & 1935 & 122 & 2345 \\
\hline
\end{tabular}

Note. World cup months are in bold. 
Table 2: Daily number of reported domestic violence incidents during June 2002, 2006 and 2010. Dates of the England games are highlighted in bold. Lost matches are in bold italic.

\begin{tabular}{|l|l|l|l|l|l|l|l|}
\hline & Monday & Tuesday & Wednesday & Thursday & Friday & Saturday & Sunday \\
\hline \multicolumn{7}{|c|}{ June 2002 $\left(1^{\text {st }}-30^{\text {th }}\right.$ June $)$} \\
\hline Week 1 & & & & & & 75 & 78 \\
Week 2 & 75 & 67 & 58 & 41 & 71 & 61 & 51 \\
Week 3 & 47 & 41 & 43 & 42 & 33 & 80 & 84 \\
Week 4 & 35 & 38 & 46 & 42 & 49 & 61 & 65 \\
Week 5 & 30 & 38 & 27 & 43 & 44 & 52 & 79 \\
\hline Average & 46.7 & 46.0 & 43.7 & 42 & 38.5 & 62.3 & 69.7 \\
\hline
\end{tabular}

\begin{tabular}{|l|l|l|l|l|l|l|l|}
\hline \multicolumn{7}{|c|}{ June/July $2006\left(1^{\text {st }}\right.$ june-2 ${ }^{\text {nd }}$ July $)$} \\
\hline Week 1 & & & & 41 & 38 & 83 & 62 \\
Week 2 & 43 & 54 & 44 & 47 & 50 & 99 & 79 \\
Week 3 & 58 & 48 & 44 & 57 & 49 & 72 & 71 \\
Week 4 & 52 & 56 & 47 & 39 & 47 & 59 & 84 \\
Week 5 & 54 & 51 & 49 & 46 & 59 & 100 & 85 \\
\hline Average & 51.7 & 51.0 & 46.0 & 43.3 & 48.6 & 71.3 & 74.2 \\
\hline
\end{tabular}

\begin{tabular}{|l|l|l|l|l|l|l|l|}
\hline \multicolumn{7}{|c|}{ June 2010 (1 $1^{\text {st }}$ June-30 ${ }^{\text {th }}$ June $)$} \\
\hline Week 1 & & 59 & 53 & 67 & 73 & 88 & 81 \\
Week 2 & 79 & 65 & 46 & 72 & 62 & 79 & 86 \\
Week 3 & 63 & 68 & 61 & 61 & 65 & 87 & 103 \\
Week 4 & 83 & 64 & 114 & 82 & 95 & 98 & 140 \\
Week 5 & 78 & 78 & 78 & & & & \\
\hline Average & 75.7 & 66.8 & 59.5 & 70.5 & 76.7 & 91.0 & 90.0 \\
\hline
\end{tabular}

*The incidents for days with England games are excluded from the daily averages 
Table 3. Negative binomial model for daily domestic violence incidents: Relative risks, confidence intervals and $p$-values..

\begin{tabular}{|r|r|l|r|}
\hline & Relative risk & $\begin{array}{l}\text { 95\% Confidence. } \\
\text { Interval }\end{array}$ & $\begin{array}{l}\text { p- } \\
\text { value }\end{array}$ \\
\hline 2002 & & & \\
\hline 2006 & $* 1.000$ & & \\
\hline Year 2010 & $* * * 1.520$ & $(1.393,1.655)$ & $<0.001$ \\
\hline & & & \\
\hline Type of day Non-match day & 1.000 & & \\
\hline Match day England win or draw & $* * * 1.256$ & $(1.128,1.411)$ & $<0.001$ \\
\hline Match day England lose & $* * 1.382$ & $(1.150,1.661)$ & 0.001 \\
\hline Day after England match day & $* 1.107$ & $(1.004,1.228)$ & 0.042 \\
\hline & & & \\
\hline Thursday & 1.000 & & 0.504 \\
\hline Friday & 1.048 & $(0.914,1.201)$ & $<0.001$ \\
\hline Saturday & $* * * 1.435$ & $(1.259,1.634)$ & $<0.001$ \\
\hline Sunday & $* * * 1.506$ & $(1.323,1.715)$ & 0.130 \\
\hline Monday & 1.112 & $(0.969,1.277)$ & 0.355 \\
\hline Tuesday & 1.067 & $(0.930,1.223)$ & 0.956 \\
\hline Wednesday & 1.004 & $(0.875,1.151)$ & \\
\hline & & & \\
\hline Theta & $* * * 0.0124$ & $(0.0064,0.0239)$ & $<0.001$ \\
\hline
\end{tabular}

Note: Significance: ${ }^{*} p<0.05,{ }^{* *} p<0.01,{ }^{* * *} p<0.001$. P-values are based on Wald tests apart from that for theta, which is based on a likelihood ratio test. 